\title{
DESAFIANDO A VOCAÇÃO DA METRÓPOLE: UMA ANÁLISE DOS DISCURSOS PRESENTES NAS DISPUTAS PELO USO DA AVENIDA PAULISTA NA CIDADE DE SÃO PAULO
}

\author{
ANTONIO FAGNER DA SILVA BASTOS ${ }^{1}$ \\ SÉRGIO CARVALHO BENÍCIO DE MELLO
}

\author{
Universidade Federal de Pernambuco \\ Programa de Pós-Graduação em Administração \\ Av. dos Funcionários, s/n, $1^{\circ}$ andar, Cidade Universitária \\ 50740-580, Recife-PE
}

$\underline{\text { fagnersbastos@gmail.com ; sergio.benicio@gmail.com }}$

\begin{abstract}
Resumo. Em 2015, a Prefeitura de São Paulo resolveu fechar a Avenida Paulista para os veículos automotores e abrir para as pessoas aos domingos e feriados. A medida gerou diversos embates entre grupos contrários e favoráveis. $O$ objetivo do artigo é identificar que discursos estiveram presentes na ressignificação do uso do espaço da Avenida Paulista na cidade de São Paulo. No trabalho, de caráter qualitativo, usamos de fontes secundárias para construção do arquivo de pesquisa. Para identificarmos os discursos presentes na abertura da Avenida Paulista, fizemos uso da Análise do Discurso Foucaultiana (ADF) como método. Os resultados apontaram que vivência urbana, participação social, respeito à vocação da cidade para os fluxos e má gestão foram os discursos que permearam o embate, o que reverbera na disputa pelo modelo ideal de cidade que os sujeitos envolvidos defendem.
\end{abstract}

Palavras-chave: Avenida Paulista; planejamento urbano; Foucault.

\begin{abstract}
Abstratct. In 2015, the City of São Paulo decided to close Avenida Paulista for motor vehicles and open to people on Sundays and holidays. The measure has generated conflicts between opposing and favorable groups. The purpose of this article is to identify which discourses were present in the redetermination of the use of the Paulista Avenue space in the city of São Paulo. In this work, which is qualitative, we use secondary sources to construct the research file. To identify the discourses present at the Paulista Avenue opening, we used the Foucaultian Discourse Analysis (ADF) as a method. The results showed that urban living, social participation, respect to the vocation of the city for the and insufficient public management were the speeches that permeated the conflict, which reverberates in the dispute for the ideal model of city that the subjects involved defend.
\end{abstract}

Keywords: Paulista Avenue; urban planning; Foucault.

\footnotetext{
${ }^{1}$ Doutorando no Programa de Pós-graduação em Administração da Universidade Federal de Pernambuco.

2 Professor da Universidade Federal de Pernambuco e bolsista de produtividade em pesquisa nível 1D do CNPq; atua no Programa de Pós-graduação em Administração.
} 


\section{INTRODUÇÃO}

Em 2015, a Prefeitura de São Paulo resolveu fechar a Avenida Paulista para os veículos automotores e abrir para as pessoas aos domingos e feriados. A medida era oriunda do Programa Ruas Abertas, que tinha por objetivo o impedimento do trânsito de veículos motorizados em algumas vias da cidade de São Paulo com a intenção de que estas recebessem atividades esportivas, gastronômicas e culturais gratuitas, e com isso se incentivasse a apropriação dos espaços públicos pela população, consolidando as relações sociais nos bairros (PMSP, 2015).

No entanto, de agosto de 2014, quando duas entidades da sociedade civil - a Rede MinhaSampa e o Movimento SampaPé - iniciaram uma campanha virtual reivindicando à Prefeitura a criação de um novo espaço de lazer e convivência na Avenida Paulista, até 18 de outubro de 2015, quando a abertura ocorreu, tal medida gerou diversos embates entre grupos contrários e favoráveis (FOLHA, 2015; MINHASAMPA, 2016). Apesar disso, em junho de 2016, a Prefeitura publicou o Decreto $\mathrm{N}^{\circ} 57.086$, instituindo o Programa Ruas Abertas, nos termos da Política Nacional de Mobilidade Urbana. O que se consolidaria em dezembro de 2016, com o prefeito assinando a Lei 16.607/2016 para instituir o programa (PMSP, 2016).

Tendo em vista que tais mudanças geraram diversos conflitos e posições divergentes sobre sua aceitabilidade, e partindo do pressuposto da construção discursiva da realidade (FOUCAULT, 2008), nosso objetivo neste artigo é identificar que discursos estiveram presentes na ressignificação do uso do espaço da Avenida Paulista na cidade de São Paulo. O que justifica nosso trabalho é a possibilidade de que conhecer os discursos conflitantes sobre políticas públicas no espaço público das urbes possa ajudar gestores a compreenderem melhor as demandas dos sujeitos conflitantes e tentar equilibrá-las.

\section{RACIONALIDADE E SUBJETIVAÇÃO: UM MODELO DE CIDADE}

Ao iniciarmos nossas análises, não tínhamos uma teoria a priori. No entanto, com o desenrolar do artigo, visualizamos que os argumentos utilizados pelos sujeitos permeavam entre crítica e defesa do modelo de cidade que São Paulo se tornou com o advento da modernidade. Por esta, entendemos como o triunfo da racionalização em detrimento da subjetivação (TOURAINI, 1994). Lefebvre (2001) aponta que a industrialização caracterizou a sociedade moderna, com transformações ocorrendo na estrutura urbana e as cidades sendo planejada para atender as demandas de escoamento de produtos. Através disso, a máquina, e não mais o homem, passa a ser a medida para o planejamento urbano.

O planejamento urbano se deu por ideias de políticos e urbanistas como Haussmann e Le Corbusier, no qual a cidade moderna é constituída como um espaço urbano racional pelo qual a lógica da linha reta para o homem circular predomina (PFEIFFER, 1997). As novas urbanidades produziram, dentre outras coisas, conforme Simmel já afirmara em 1903, uma atitude blasé. O sujeito racional e calculista capaz de bloquear coisas. Para acomodar a vida cotidiana (falar com estranhos, comprar alimentos, ou se deslocar para o trabalho), ele teve que exercer uma espécie de reserva mental. Uma forma de enfrentamento que as pessoas adotaram para lidar com as realidades da vida 
urbana (SIMMEL, 2005). Isto somado à automobilidade ajudou a produzir um espaço público esvaziado, com suas vias servindo apenas aos automóveis. Automobilidade se refere ao viés das cidades serem planejadas e governadas de forma a atender as demandas daqueles que possuem automóveis. Tal viés tem gerado/fomentado um sistema autoorganizado, não-linear, que pressupõe e chama à existência de um conjunto de carros, motoristas, estradas, abastecimento de petróleo, novas tecnologias e outros objetos, bem como culturas e modos de governança a ele - o sistema - entrelaçados (URRY, 2008).

Em decorrência, pessoas e lugares foram sendo deixados de lado. Ocorre "a passagem de uma cidade que se constitui a partir dos homens que a ocupam, para uma cidade que é construída para que nela habitem um determinado tipo de morador" (PFEIFFER, 1997, p. 54). De acordo com a mesma autora, esse tipo de urbanização favorece o apagamento do cidadão para a construção do morador, com o sujeito deixando de pertencer à cidade, tendo direitos e deveres (nível coletivo) para se tornar um ocupante mais preocupado em defender seu espaço ocupado (nível individual).

Com isso, andar de um lugar a outro torna-se arriscado, e a qualidade amigável das ruas, sobretudo nas grandes cidades, começa a desaparecer. Ao longo dos espaços onde as pessoas tinham o costume de se reunir, vias impessoais passam a dominar. A cidade fica esvaziada, passando a servir apenas para passagem. A essência da comunidade se perde na confusão de tráfego (PROJECT FOR PUBLIC SPACES, 2008). Nas ideias de Castells (2004), os espaços de fluxos passam a dominar a cidade, e os espaços de lugar desaparecem gradativamente. Para ele, as cidades são estruturadas e desestruturadas simultaneamente pelas lógicas concorrentes do espaço de fluxos e o espaço de lugares.

Portanto, a forma de urbanismo que perdurou durante o século $\mathrm{XX}$, da visão funcionalista, calcada nas ideias de eficiência e progresso de urbanistas como Le Corbusier ajudaram a produzir uma cidade maquínica, que concede a pressa e a exigência de um automóvel como condições inelutáveis ao homem do nosso século (CORREIA, 1996). Seus defensores preferem a privacidade sobre comunidade, a separação espacial sobre a contiguidade, conveniência e redes sociais dispersas sobre bairros tradicionais (ELLIS, 2002). Quadro que não difere muito do modelo rodoviarista implementando em São Paulo (ROLNIK; KLINTOWITZ, 2011).

Porém, Jacobs (2011) nos explica que os automóveis costumam ser rotulados de vilões e responsabilizados pelos males das cidades, pelos insucessos e pela inutilidade do planejamento urbano, mas seus efeitos nocivos são menos a causa do que um sintoma da incompetência no desenvolvimento urbano em tentar solucionar os problemas complexos das cidades. Além dá complexidade já inerente às cidades, as formas de urbanização, como o uso do espaço viário, também vão se reconfigurando.

Diante do complexo cenário urbano, novas formas de se planejar a cidade emergiram. Dentre elas, o novo urbanismo. Este é uma filosofia de planejamento emergente que funde um reconhecimento da cultura urbana e história, com uma ênfase em fazer conexões humanas e físicas, estimular a participação do público nos assuntos cívicos, e melhorar o espaço de domínio público (BRAY, 1993). As estratégias do Novo Urbanismo tentam fazer com que os cidadãos se sintam parte de uma cultura que é mais significativa do que a individual, de forma a evitar a fragmentação física e a compartimentação funcional da vida moderna (KELBAUGH, 2000). Em outras palavras, a busca de uma cidade na dimensão humana. Uma preocupação crescente com a dimensão 
humana no planejamento urbano reflete uma exigência distinta e forte por melhor qualidade de vida urbana (GEHL, 2013).

No entanto, tais ideias parecem não coadunarem com a visão racional de cidade que veio sendo fomentada através dos anos e que se aproxima cada vez mais de uma visão neoliberal de desenvolvimento. O neoliberalismo afirma que o bem-estar humano pode ser melhor promovido por meio da maximização das liberdades empresariais dentro de um quadro institucional caracterizado por direitos de propriedade privada, liberdade individual, mercados e comércio livres. No qual o papel do Estado é criar e preservar um quadro institucional apropriado a estas práticas (HARVEY, 2007). E que, segundo Harvey (2007, p. 2), "se tornou hegemônico como tipo de discurso, disseminando-se pelos modos de pensar e pelas práticas político-econômicas a ponto de se incorporar ao senso comum com o qual interpretamos, vivemos e compreendemos o mundo". O que explica sua defesa pelo grupo que não quer mudanças no espaço urbano da metrópole.

São estes dois pontos de vista sobre a cidade que parecem disputar, por meio de discursos concorrentes, como a Avenida Paulista deve ser planejada e utilizada pelos seus habitantes.

\section{PROCEDIMENTOS METODOLÓGICOS}

Em nosso trabalho, que é de caráter qualitativo, usamos fontes secundárias para construção do arquivo de pesquisa. De acordo com Pereira e Chagas (2011), o arquivo é o que faz com que as coisas ditas se mantenham, segundo regras específicas, no corpo enunciativo, cuja existência e materialidade se concretizam no acontecer, e é, também, o que designa o sistema de funcionamento que possibilita a diferenciação de uma multiplicidade de existências discursivas e especifica a duração de cada uma destas existências. $\mathrm{O}$ arquivo é o sistema geral da formação e da transformação dos enunciados, é a lei do que pode ser dito, o sistema que rege o aparecimento dos enunciados como acontecimentos singulares (FOUCAULT, 2008).

O espaço temporal dos documentos escolhidos se situa entre setembro de 2013 (quando encontramos a primeira notícia relacionada a tentativas de se abrir a Avenida Paulista para pessoas e fechar para veículos) e junho de 2016 (com a publicação da Prefeitura de São Paulo de um decreto oficializando a medida). O arquivo é composto de informativos e documentos oficiais, campanhas virtuais, manifestos, posicionamentos, notas à imprensa e notícias em meios de comunicação virtuais do maior número possível de sujeitos envolvidos, totalizando 98 documentos. Conforme a pesquisa era realizada, íamos identificando as fontes discursivas. No fechamento do arquivo, chegamos a cinco fontes: o discurso do governo, representado pela Prefeitura e órgãos auxiliares; o discurso dos grupos a favor da medida, formado principalmente por organizações ativistas; o discurso mediador, identificado no Ministério Público de São Paulo; o discurso dos grupos contrários, composto por entidades da sociedade civil como ordem dos advogados do Brasil e associações de moradores da região; e por último, o discurso da mídia, que narrava os fatos que iam se sucedendo. A Figura 1 delineia as fontes que formaram o nosso arquivo. Entre parêntese está a quantidade de documentos de cada uma. Uma lista detalhada de cada documento pode ser solicitada aos pesquisadores. 
Durante nossas análises, procuramos atentar aos critérios de triangulação, reflexividade, representatividade e rica descrição propostos por Paiva Jr, Leão e Mello (2011), visando garantir validade e confiabilidade à investigação qualitativa. A triangulação se deu entre o pesquisador e orientador para validação dos achados que se deram por meio de reflexividade, com o autor buscando sempre se questionar sobre o processo investigativo. A escolha dos documentos que compõem o arquivo buscou ser representativo, incluindo os diferentes sujeitos políticos envolvidos, e tentando se chegar a saturação dos dados. E a descrição dos achados tentou ser mais rica, detalhada e clara possível.

Além disso, buscamos atender aos princípios fundamentais de raridade, exterioridade e acúmulo propostos por Foucault (2008): raridade, para evitar sobreposições e a pletora de significados; exterioridade, para que o contexto possa dizer o que é permitido e o que não é; e acúmulo, para se procurar as regularidades dos enunciados e não suas origens ou fundamentos últimos.

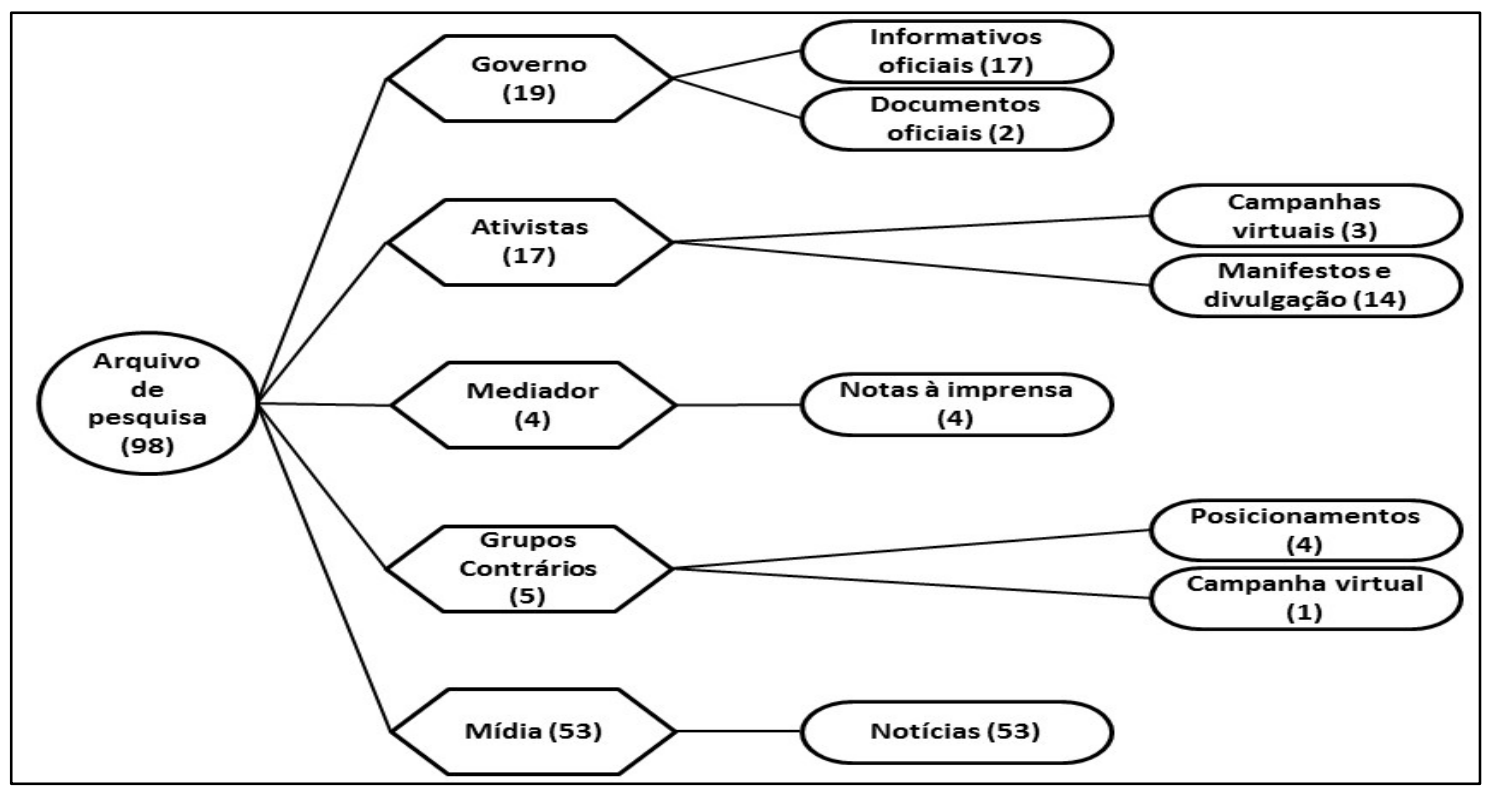

Figura 1: Arquivo de pesquisa.

Para identificarmos em nosso arquivo os discursos associados à abertura da Avenida Paulista, fizemos uso da Análise do Discurso Foucaultiana (ADF) como método. Essa abordagem se debruça sobre discursos de forma a compreender formações ali presentes, a partir da identificação de seus enunciados (LEÃO, FEREIRA, GOMES, 2016). "Chamaremos de discurso um conjunto de enunciados, na medida em que se apoiem na mesma formação discursiva" (FOUCAULT, 2008, p. 132).

Foucault entende que as ciências humanas podem ser observadas como sistemas autônomos de discurso nos quais instituições sociais exercem influência sobre as práticas discursivas. Por isso, ele recomenda investigar os discursos das ciências humanas sem envolver-se no debate se aquilo que afirmam é ou não verdade, ou se suas proposições são plausíveis, sem a pretensão de elaborar uma teoria absoluta sobre as regras que 
governariam os sistemas das práticas discursivas (GONÇALVES, 2009), mas, também, sem a pretensão de se tentar produzir um conhecimento neutro.

Foucault (2008) afirma que antes de se ocupar, com toda certeza, de uma ciência, ou de romances, ou de discursos políticos, ou da obra de um autor, ou mesmo de um livro, o material que temos a tratar, em sua neutralidade inicial, é uma população de acontecimentos no espaço do discurso em geral.

A análise dos acontecimentos discursivos não está, de maneira alguma, limitada a semelhante domínio; e, por outro lado, o recorte do próprio domínio não pode ser considerado como definitivo, nem como válido de forma absoluta; trata-se de uma primeira aproximação que deve permitir o aparecimento de relações que correm o risco de suprimir os limites desse primeiro esboço. (FOUCAULT, 2008, p. 34)

Considerando as políticas de acalmamento do trânsito (traffic calming) da cidade de São Paulo um acontecimento histórico do qual deriva a abertura/fechamento da avenida Paulista como acontecimento discursivo, utilizamos a ADF para identificar os discursos presentes na construção de tal acontecimento.

A ADF é justamente a descoberta das condições de possibilidades de certos saberes (LEÃO, FEREIRA, GOMES, 2016). A questão da ADF é descobrir quais enunciados se agrupam, com certas funções, sob determinadas regras para gerarem formações discursivas presentes no acontecimento estudado sem negligenciar nenhuma forma de descontinuidade, de corte, de limiar ou de limite. Ou nas palavras de Foucault (2008, p. 30),

eis a questão que a análise da língua coloca a propósito de qualquer fato de discurso: segundo que regras um enunciado foi construído e, consequentemente, segundo que regras outros enunciados semelhantes poderiam ser construídos? A descrição de acontecimentos do discurso coloca uma outra questão bem diferente: como apareceu um determinado enunciado, e não outro em seu lugar?

Logo, alguns conceitos propostos por Foucault precisam ser melhor delineados para o entendimento da ADF: enunciados, funções enunciativas, regras de formação e formações discursivas.

$\mathrm{Na} \mathrm{ADF}$, os enunciados podem ser considerados como as unidades elementares do discurso. São os átomos do discurso. Foucault (2008, p. 98) explica que o enunciado [...] não é em si mesmo uma unidade, mas sim uma função que cruza um domínio de estruturas e de unidades possíveis e que faz com que apareçam, com conteúdos concretos, no tempo e no espaço. Quanto a sua forma, o enunciado não equivale a frases, a proposições ou a atos de fala. Embora, possa assumir tais formas para ser materializado.

As funções enunciativas indicam como o enunciado "age" (LEÃO, FEREIRA, GOMES, 2016). O que ele enuncia. "Uma série de signos se tornará enunciado com a condição de que tenha com 'outra coisa' uma relação específica que se refira a ela mesma - e não à sua causa, nem a seus elementos" (FOUCAULT, 2008, p.100). Há quatro critérios para se identificara função de um enunciado: referencial, sujeito, campo associado e materialidade. 
O referencial é constituído de "leis de possibilidade, de regras de existência para os objetos que aí se encontram nomeados, designados ou descritos, para as relações que aí se encontram afirmadas ou negadas" (FOUCAULT, 2008, p.103). Fischer (2001) afirma que é a referência do que identificamos. Outro critério é a identificação do sujeito. Para que uma série de signos exista, é preciso um "autor" ou uma instância produtora. No entanto, para Foucault (2008), o sujeito é um lugar determinado e vazio que pode ser efetivamente ocupado por indivíduos variados que produzem os diferentes enunciados. É a posição que pode ser ocupada por alguém que pode efetivamente afirmar um enunciado (FISCHER, 2001). O campo associado trata de toda a adjacência a que um enunciado se relaciona e que pode identificá-lo. Ou seja, o enunciado não pode existe de forma isolada. Segundo Foucault (2008), a função enunciativa não pode se exercer sobre uma frase ou proposição em estado livre pois um enunciado tem sempre margens povoadas de outros enunciados. O último critério das funções enunciativas é a materialidade. Ou seja, o enunciado carece de existência material.

As regras de formação são as condições de existência (mas também de coexistência, de manutenção, de modificação e de desaparecimento) em uma dada repartição discursiva (FOUCAULT, 2008). Ele fornece quatro diferentes regras: objetos, modalidade de enunciação, conceitos, escolhas temáticas.

A formação dos objetos diz respeito a tentativa de se identificar os relacionamentos que caracterizam uma prática discursiva. De acordo com Foucault (2008), tal formação é assegurada por um conjunto de relações estabelecidas entre instâncias de emergência, de delimitação e de especificação. A formação das modalidades enunciativas trata, segundo Foucault (2008), de um certo estilo de enunciação, pelo qual podem ser determinadas a dispersão do sujeito e sua descontinuidade em relação a si mesmo através do status, lugar e situação. A formação dos conceitos aponta o estabelecimento de grupos de enunciados, descrevendo a organização em que aparecem e circulam. Essa organização compreende formas de sucessão, formas de coexistência e procedimentos de intervenção. A formação das estratégias versa sobre a descrição de seu encadeamento e explicação das formas unitárias sob as quais elas se apresentam. São os temas e teorias estabelecidos na materialidade do discurso que compreende determinar os pontos de difração possíveis do discurso, descrever instâncias específicas de decisão e relatar a função que deve exercer o discurso estudado em um campo de práticas não discursivas (FOUCAULT, 2008).

As formações discursivas são os agrupamentos de enunciados que possuem determinadas funções, sob certas regras de formação. Assim, quando se puder descrever, dentre um número de enunciados, com semelhante sistema de dispersão, e que entre os objetos, os tipos de enunciação, os conceitos, as escolhas temáticas, se puder definir uma regularidade haverá uma formação discursiva (FOUCAULT, 2008). E como encontrar essa regularidade de um discurso? Para Leão, Ferreira e Gomes (2016), é a análise do discurso que propicia que entendamos um discurso a partir de certa regularidade, identificável em suas formações. De acordo com Foucault (2008, p. 122), uma formação discursiva "é conjunto de enunciados que se apoia em um mesmo sistema de formação".

A formação discursiva não é, no entanto, um elemento fixo. Ela não desempenha o papel de uma figura que para no tempo. E sim determina uma regularidade própria de processos temporais, colocando o princípio de articulação entre uma série de acontecimentos discursivos e outras séries de acontecimentos, transformações, mutações e processos (FOUCAULT, 2008). 


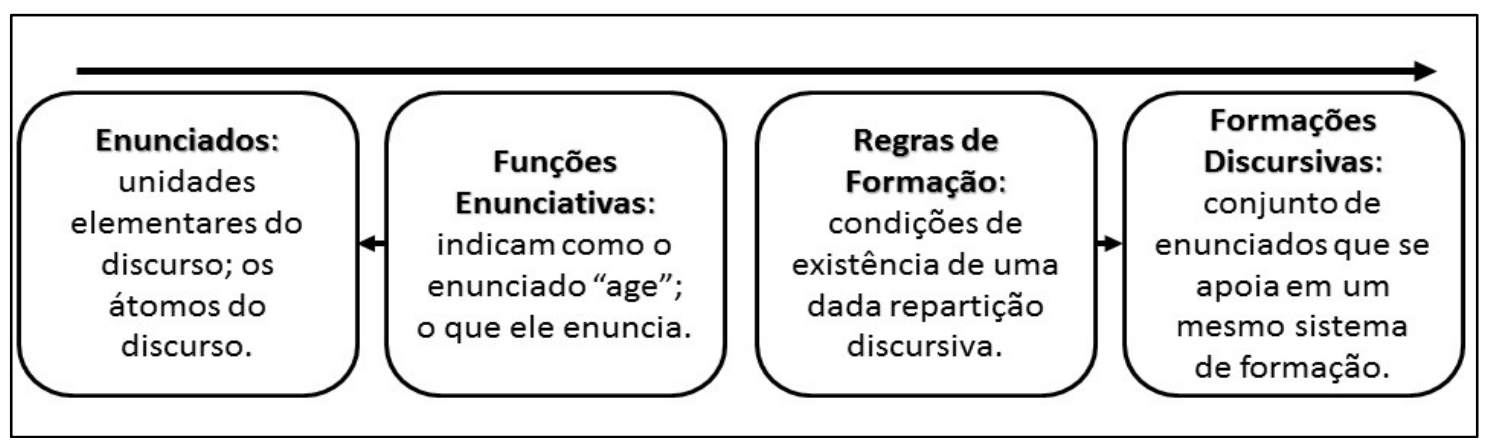

Figura 2 - Etapas da Análise de Discurso Foucaultiana, baseado em Leão, Ferreira e Gomes (2016).

Portanto, a partir das formações discursivas obtidas é que poderemos melhor problematizar o objeto estudado, entender suas regularidades e como foi possível ele vir a ser o que é.

\section{RESULTADOS: OS DISCURSOS QUE PERMEARAM A ABERTURA DA PAULISTA}

Realizamos uma ADF em busca das formações discursivas que permearam a abertura/fechamento da Avenida Paulista. A partir dos resultados aqui encontrados pudemos na seção posterior apontar tais discursos e discutir sobre o objeto estudado.

\subsection{ENUNCIADOS}

Assim, inicialmente, identificamos os enunciados presentes em nosso arquivo de pesquisa. Com base em Leão, Ferreira e Gomes (2016), os descrevemos como proposições afirmativas, buscando revelar não só suas características, mas também uma ideia clara de significação em seu contexto. Na Tabela 1, anotamos todos os 39 enunciados identificados e uma breve explicação sobre cada um.

Após as primeiras análises, foi possível observar uma relação antagônica momentânea sobre a abertura/fechamento da Avenida Paulista entre Governo e Mediador, o primeiro sendo apoiado pelos Grupos Favoráveis e o segundo tendo o respaldo dos Grupos Contrários. Boa parte dos enunciados foi identificada nos discursos do Governo e dos Grupos Favoráveis. Destes podemos citar: E1, E2, E3, E5, E8, E9, E12, E13, E14, E15, E18, E20, E21, E23, E24, E26, E31, E35. O que indica consonância de ideias entre esses grupos.

Além disso, apenas nos grupos favoráveis foram identificados os seguintes enunciados: E7, E19, E28, E32, E38, E39. Outra parte significativa de enunciados foram identificados nos discursos do Mediador e dos Grupos Contrários. O que indica alinhamento de ideias entre esses dois grupos. Os enunciados em questão são: E4, E10, E11, E16, E17 E22. E25, E29, E30. Nos grupos contrários também identificamos alguns enunciados específicos: E27, E29, E33, E34. 
Alguns enunciados foram encontrados em ambas as posições (contrárias e favoráveis), o que representa pontos de conformidade de ideias entre os divergentes. São eles: E6, E36, E37. Na Mídia, quase todos os enunciados apareceram. As exceções foram dos enunciados, anteriormente citados, exclusivos dos grupos favoráveis. Salientamos que o enunciado E32 foi descontinuado. Ou seja, desapareceu nas análises que se seguiram. $\mathrm{O}$ que se deu devido à mudança de postura da Prefeitura frente a ideia de se abrir a Avenida para pedestres.

Tabela 1 - Lista de Enunciados identificados no arquivo.

\begin{tabular}{|c|c|c|}
\hline E1 & $\begin{array}{l}\text { A Av. Paulista pode ser } \\
\text { utilizada para o convívio }\end{array}$ & $\begin{array}{l}\text { Profere sobre a possiblidade do espaço viário da Avenida Paulista ser } \\
\text { utilizado para finalidades de socialização, lazer, atividade física e outros } \\
\text { usos que não o tráfego. }\end{array}$ \\
\hline E2 & $\begin{array}{l}\text { A abertura é uma PP e não } \\
\text { um evento }\end{array}$ & $\begin{array}{l}\text { Alega que a abertura da Avenida Paulista é uma política pública e não } \\
\text { um evento privado e por isso a medida não seria afetada pelo Termo de } \\
\text { Ajustamento de Conduta assinado junto ao Ministério Público. }\end{array}$ \\
\hline E3 & $\begin{array}{r}\text { As externalidad } \\
\text { pela abertura p } \\
\text { contorna } \\
\end{array}$ & $\begin{array}{l}\text { Defende que todas as externalidades geradas pela abertura da Paulista, } \\
\text { como o acesso de moradores, o acesso a hospitais, o tráfego na região, } \\
\text { podem ser contornadas pela equipe técnica da Prefeitura. }\end{array}$ \\
\hline E4 & $\begin{array}{l}\text { O espaço da Paulista deve } \\
\text { ser utilizado como planejado } \\
\text { previamente }\end{array}$ & $\begin{array}{l}\text { Argumenta que o espaço para circulação dos automóveis não pode ser } \\
\text { proibido para que se garanta o direito à locomoção e a uma cidade } \\
\text { ordenada conforme foi inicialmente planejada.. }\end{array}$ \\
\hline E5 & $\begin{array}{r}\text { A popr } \\
\text { apro }\end{array}$ & $\begin{array}{l}\text { que tanto a população em geral como a dos entornos da Paulista } \\
\text { abertura. }\end{array}$ \\
\hline E6 & $\begin{array}{r}\text { A Av. I } \\
\text { represent } \\
\text { paul }\end{array}$ & $\begin{array}{l}\text { Diz que a Avenida é simbólica para a cidade e para o paulistano. É a } \\
\text { mais importante e famosa da cidade e as transformações que lá ocorrem } \\
\text { servem de modelo para o resto da cidade. }\end{array}$ \\
\hline E7 & $\begin{array}{l}\text { O uso da Paulista aberta deve } \\
\text { ser livre }\end{array}$ & $\begin{array}{l}\text { Profere que o uso do espaço da Paulista durante a abertura deve ser livre, } \\
\text { com os todos os diferentes públicos se apropriando como bem queiram } \\
\text { do espaço. }\end{array}$ \\
\hline E8 & $\begin{array}{l}\text { A abertura é uma medida } \\
\text { includente }\end{array}$ & $\begin{array}{l}\text { a política proporciona a usuários, como pedestres, ciclistas, } \\
\text { a possibilidade de utilizar o espaço da avenida que foi } \\
\text { para atender apenas modais motorizados. }\end{array}$ \\
\hline E9 & $\begin{array}{l}\text { Estudos técnicos respaldam a } \\
\text { abertura da Paulista }\end{array}$ & $\begin{array}{l}\text { Ressalta que a abertura da Paulista possui respaldo de diferentes estudos } \\
\text { técnicos. E que os mesmo são suficientes para dar sustentação à } \\
\text { abertura. }\end{array}$ \\
\hline E10 & $\begin{array}{r}\text { Os estudos r } \\
\text { fecham } \\
\text { insuf }\end{array}$ & $\begin{array}{l}\text { ue os estudos realizados pela Prefeitura são insuficientes para } \\
\text { entação ao fechamento de uma avenida tão importante para a } \\
\text { í da cidade como é a Paulista. }\end{array}$ \\
\hline E11 & $\begin{array}{l}\text { O fechamento desrespeita } \\
\text { acordo previamente firmado }\end{array}$ & $\begin{array}{l}\text { o descumpre um acordo (TAC) firmado em } \\
\text { Ministério Público que limitava a três vezes por } \\
\text { nida Paulista. }\end{array}$ \\
\hline E12 & $\begin{array}{l}\text { A aberts } \\
\text { da }\end{array}$ & $\begin{array}{l}\text { de abrir a avenida para pedestres aos } \\
\text { edade civil. }\end{array}$ \\
\hline E13 & $\begin{array}{r}\text { PP } \\
\text { es } \\
\text { te }\end{array}$ & $\begin{array}{l}\text { Reitera que políticas semelhantes vem sendo implementadas também } \\
\text { em outras metrópoles mundiais. }\end{array}$ \\
\hline E14 & & $\begin{array}{l}\text { roclama que a medida colabora pra um olhar mais humano sobre a } \\
\text { idade que coaduna com ideias de cooperação, socialização e } \\
\text { oletividade. }\end{array}$ \\
\hline E15 & $\begin{array}{r}\text { O sucesso da a } \\
\text { depende do envol } \\
\text { vários ator }\end{array}$ & $\begin{array}{l}\text { Reconhece que é necessário o envolvimento de vários atores } \\
\text { (governamentais, técnicos, sociais) para a efetividade da medida. }\end{array}$ \\
\hline E16 & $\begin{array}{l}\text { O fechamento da Paulista } \\
\text { gera prejuízos ao comércio } \\
\text { da região }\end{array}$ & $\begin{array}{l}\text { Relata que o fechamento da avenida é prejudicial para o comércio da } \\
\text { região, tendo em vista que os clientes não poderão ir de carro até a } \\
\text { região. }\end{array}$ \\
\hline E17 & $\begin{array}{l}\text { A decisão de fechar a } \\
\text { Paulista foi autocrática }\end{array}$ & $\begin{array}{l}\text { Denuncia que a implementação da política se deu por parte da Prefeitura } \\
\text { sem esta discutir a questão com a população nem cumprir todas as } \\
\text { recomendações propostas. }\end{array}$ \\
\hline E18 & $\begin{array}{c}\text { A abertura garante a } \\
\text { segurança dos usuários da PP }\end{array}$ & $\begin{array}{l}\text { Defende que o impedimento do trânsito de veículos motorizados na } \\
\text { Paulista durante a medida garante a segurança dos usuários. }\end{array}$ \\
\hline
\end{tabular}




\begin{tabular}{|c|c|c|}
\hline E19 & $\begin{array}{l}\mathrm{O} \text { TAC está anacrônico às } \\
\text { novas visões de cidade }\end{array}$ & $\begin{array}{l}\text { Explana que as novas demandas por apropriação do espaço urbano pela } \\
\text { população não são contempladas pelo TAC firmado e que por isso este } \\
\text { precisa ser revisto. }\end{array}$ \\
\hline E20 & $\begin{array}{l}\text { A abertura favorece alguns } \\
\text { setores comerciais }\end{array}$ & $\begin{array}{l}\text { Aponta que alguns setores comerciais, como restaurantes, pontos } \\
\text { culturais e comércio informal, estão se beneficiando da abertura da } \\
\text { Paulista. }\end{array}$ \\
\hline E21 & $\begin{array}{l}\text { A abertura está de acordo } \\
\text { com a PNMU }\end{array}$ & $\begin{array}{l}\text { Declara que a abertura da Avenida Paulista para lazer está respaldada } \\
\text { pela Política Nacional de Mobilidade Urbana. }\end{array}$ \\
\hline E22 & $\begin{array}{c}\text { O fechamento gera } \\
\text { transtornos para os } \\
\text { moradores da região }\end{array}$ & $\begin{array}{l}\text { Alega que o fechamento gera diversos transtornos para os moradores da } \\
\text { região. Tais como barulho, sujeira, aumento da criminalidade, } \\
\text { problemas de acesso, entre outros. }\end{array}$ \\
\hline E23 & $\begin{array}{l}\text { Usuários da Paulista já estão } \\
\text { habituados ao seu } \\
\text { fechamento por protestos }\end{array}$ & $\begin{array}{l}\text { Profere que a Avenida Paulista tem histórico constante de fechamento } \\
\text { para protestos e outras manifestações e por isso, seus usuários já estão } \\
\text { habituados ao seu fechamento. }\end{array}$ \\
\hline E24 & $\begin{array}{l}\text { A continuidade da abertura } \\
\text { carece de sustentação legal }\end{array}$ & $\begin{array}{l}\text { Evoca que por se tratar de uma medida passível de reversão, é } \\
\text { necessário a criação de instrumentos legais que garantam a continuidade } \\
\text { da política em futuras gestões. }\end{array}$ \\
\hline E25 & $\begin{array}{l}\text { A aprovação popular do } \\
\text { fechamento é duvidosa }\end{array}$ & $\begin{array}{l}\text { Alerta que a aprovação da medida da população ainda não está } \\
\text { consolidada e as pesquisas realizadas até o momento ainda são } \\
\text { insuficientes para se tirar conclusões. }\end{array}$ \\
\hline E26 & $\begin{array}{l}\text { A abertura da Paulista se deu } \\
\text { de forma democrática }\end{array}$ & $\begin{array}{l}\text { Ressalta que a Prefeitura discutiu com a população interessada a } \\
\text { implementação da medida e cumpriu as recomendações exigidas pelos } \\
\text { órgãos fiscalizadores. }\end{array}$ \\
\hline E27 & $\begin{array}{l}\text { O fechamento da Paulista é } \\
\text { uma medida excludente }\end{array}$ & $\begin{array}{l}\text { Invoca que a medida retira de alguns usuários (de modais motorizados) } \\
\text { o direito de se locomover pela avenida. }\end{array}$ \\
\hline E28 & $\begin{array}{l}\text { A abertura gera menos } \\
\text { poluição sonora e } \\
\text { atmosférica }\end{array}$ & $\begin{array}{l}\text { Afirma que durante a abertura da paulista, os níveis de poluição são } \\
\text { menores do que nos períodos de uso habitual. }\end{array}$ \\
\hline E29 & $\begin{array}{r}\text { O fechamentc } \\
\text { prejudicial p } \\
\text { hosp }\end{array}$ & $\begin{array}{l}\text { Profere que a medida prejudica o acesso de ambulâncias aos hospitais } \\
\text { presentes na área da avenida. }\end{array}$ \\
\hline E30 & $\begin{array}{l}\text { O fechamento da Paulista } \\
\text { gera congestionamentos na } \\
\text { região }\end{array}$ & $\begin{array}{l}\text { alega que medida causa congestionamentos na região, tendo em vista } \\
\text { que sobrecarrega o trânsito das adjacências. }\end{array}$ \\
\hline E31 & $\begin{array}{l}\text { A participação da sociedade } \\
\text { é necessária para a } \\
\text { continuidade da abertura }\end{array}$ & $\begin{array}{l}\text { Diz que a continuidade da medida depende tanto do apoio popular como } \\
\text { de sua participação na gestão da política. }\end{array}$ \\
\hline E32 & $\begin{array}{l}\text { Inicialmente, a Prefeitura não } \\
\text { apoia o fechamento da } \\
\text { Avenida Paulista }\end{array}$ & $\begin{array}{l}\text { Evoca que a Prefeitura precisou ser convencida a aceitar a ideia de se } \\
\text { abrir a Paulista para pedestres. }\end{array}$ \\
\hline E33 & & $\begin{array}{l}\text { Afirma que a medida é uma estratégia para desviar a atenção dos erros } \\
\text { da atual gestão e angariar certo eleitorado mais progressista. }\end{array}$ \\
\hline E34 & $\begin{array}{l}\text { O fechamento demanda } \\
\text { recursos que poderiam ser } \\
\text { aplicados em outras PP }\end{array}$ & $\begin{array}{l}\text { Defende que a cidade possui outros problemas a serem resolvidos e que } \\
\text { os recursos (humanos e financeiros) utilizados para fechar a avenida } \\
\text { poderiam ajudar na questão. }\end{array}$ \\
\hline E35 & $\begin{array}{r}\text { A abertura ten } \\
\text { urbanis }\end{array}$ & $\begin{array}{l}\text { Anuncia o respaldo de especialistas sobre a questão urbana para com a } \\
\text { medida. }\end{array}$ \\
\hline E36 & $\begin{array}{l}\text { O uso durante o fechamento } \\
\text { da Paulista deveria ser } \\
\text { regulado }\end{array}$ & $\begin{array}{l}\text { Sugere a ordenação e controle das atividades exercidas pelos usuários } \\
\text { durante o fechamento da avenida. }\end{array}$ \\
\hline E37 & $\begin{array}{l}\text { A Paulista tem alto fluxo de } \\
\text { pedestres }\end{array}$ & $\begin{array}{l}\text { Reitera que a Paulista possui um alto fluxo de pedestres, seja turistas, } \\
\text { trabalhadores e moradores. }\end{array}$ \\
\hline E38 & $\begin{array}{l}\text { A abertura de vias favorece a } \\
\text { saúde pública }\end{array}$ & $\begin{array}{l}\text { Declara que a abertura colabora com questões de saúde pública como } \\
\text { qualidade de vida. }\end{array}$ \\
\hline E39 & $\begin{array}{l}\text { A abertura vai contra ideais } \\
\text { de higienização enraizados } \\
\text { na cidade }\end{array}$ & $\begin{array}{l}\text { Argumenta que grupos contrários impõem barreiras sociais ao uso da } \\
\text { paulista. }\end{array}$ \\
\hline
\end{tabular}




\subsection{FUNÇÕES ENUNCIATIVAS}

A segunda etapa de nossa ADF foi identificar as Funções Enunciativas a que os Enunciados denotavam. Seguindo o modelo proposto por Leão, Ferreira e Gomes (2016), elas foram escritas em orações iniciadas com verbo no infinitivo, de maneira a enfatizar que se referem a uma "ação" dos enunciados aos quais se relacionam. Na Tabela 2, as apresentamos. Cabe ressaltar que alguns critérios (referencial, sujeito, campo, materialidade) carecem de ser considerados para a elaboração das funções. Os referenciais encontrados foram uso, gestão, funcionamento e importância da Avenida. Os sujeitos foram o governo, grupos contrários, os usuários, especialistas e os ativistas. Os campos associados referem-se ao convívio urbano, ao simbólico, legal, político, técnico, habitacional e ao utilitário. E quanto à materialidade, encontramos sociabilidade, identificação, política pública, má gestão, participação, estudos, circulação, funcionamento, continuidade.

Tabela 2 - Lista de Funções Enunciativas identificados no arquivo.

\begin{tabular}{|c|c|c|c|c|}
\hline Funções enunciativas & Referencial & Sujeito & Campo & Materialidade \\
\hline $\begin{array}{l}\text { FE1: Apontar a possibilidade de se usar o } \\
\text { espaço público da Av. Paulista para o } \\
\text { convívio urbano }\end{array}$ & $\begin{array}{l}\text { Uso do Espaço } \\
\text { Público }\end{array}$ & $\begin{array}{l}\text { Ativistas/ } \\
\text { Governo }\end{array}$ & Convívio urbano & Sociabilidade \\
\hline $\begin{array}{l}\text { FE2: Demonstrar a representatividade da Av. } \\
\text { Paulista para a cidade de São Paulo }\end{array}$ & $\begin{array}{l}\text { Importância da } \\
\text { Avenida }\end{array}$ & Todos & Simbólico & Identificação \\
\hline $\begin{array}{l}\text { FE3: Evidenciar a legalidade da abertura da } \\
\text { Paulista }\end{array}$ & $\begin{array}{l}\text { Gestão do espaço } \\
\text { público }\end{array}$ & Governo & Legal & Política Pública \\
\hline $\begin{array}{l}\text { FE4: Alegar que o fechamento da Paulista } \\
\text { gerará transtornos para a região }\end{array}$ & $\begin{array}{l}\text { Funcionamento } \\
\text { do lugar }\end{array}$ & Grupos contrários & Habitacional & Má gestão \\
\hline $\begin{array}{l}\text { FE5: Apontar a falta de respaldo legal do } \\
\text { fechamento da Paulista }\end{array}$ & $\begin{array}{l}\text { Gestão do espaço } \\
\text { público }\end{array}$ & Grupos contrários & Legal & Política Pública \\
\hline FE6: Evidenciar o apoio popular à iniciativa & $\begin{array}{l}\text { Uso do Espaço } \\
\text { Público }\end{array}$ & $\begin{array}{l}\text { Ativistas/ } \\
\text { Governo }\end{array}$ & Político & Participação \\
\hline $\begin{array}{l}\text { FE7: Evidenciar que a abertura tem respaldo } \\
\text { de especialistas e estudos técnicos }\end{array}$ & $\begin{array}{l}\text { Gestão do Espaço } \\
\text { Público }\end{array}$ & $\begin{array}{c}\text { Governo/ } \\
\text { Especialistas }\end{array}$ & Técnico & Estudos \\
\hline $\begin{array}{l}\text { FE8: Apontar que o fechamento desafia a } \\
\text { vocação da cidade para os fluxos }\end{array}$ & $\begin{array}{l}\text { Uso do Espaço } \\
\text { Público }\end{array}$ & Grupos contrários & Utilitário & Circulação \\
\hline $\begin{array}{l}\text { FE9: Demonstrar a viabilidade para o } \\
\text { funcionamento da Paulista Aberta }\end{array}$ & $\begin{array}{c}\text { Gestão do espaço } \\
\text { público }\end{array}$ & $\begin{array}{c}\text { Ativistas/ } \\
\text { Governo }\end{array}$ & Técnico & Funcionamento \\
\hline FE10: Assegurar a continuidade da abertura & $\begin{array}{l}\text { Gestão do espaço } \\
\text { público }\end{array}$ & Ativistas & Político & Prossecução \\
\hline $\begin{array}{l}\text { FE11: Denunciar o uso do fechamento da } \\
\text { Paulista para ocultar a má gestão da cidade }\end{array}$ & $\begin{array}{l}\text { Gestão do espaço } \\
\text { público }\end{array}$ & Grupos contrários & Utilitário & Má gestão \\
\hline
\end{tabular}

Os enunciados relacionados a cada uma serão indicados mais à frente na subseção das formações discursivas 


\subsection{REGRAS DE FORMAÇÃO}

A terceira etapa da ADF é apresentar as regras de formação, juntamente com seus critérios. Para a primeira regra, demos o nome "Nova Cidade". Ela é formada pelas funções enunciativas FE1, FE2 e FE6. A segunda regra é "Participação Social" e é composta pelas funções FE6 e FE7. À terceira regra, chamamos "Governança" e é oriunda das funções FE3, FE7, FE9 e FE10. A quarta regra é "Vocação aos Fluxos" e procede das funções FE4 e FE8. A última regra, nomeamos de "Má Gestão" e é composta pelas funções FE4, FE5, FE8 e FE11.

Tabela 3 - Regras de Formação.

\begin{tabular}{l} 
Nova Cidade: A regra sugere que o paradigma de circulação que rege a metrópole de São Paulo pode ser \\
mudado para a criação de uma nova cidade capaz de transformar alguns de seus espaços em lugares de \\
vivência e de convivência. \\
\hline Participação Social: Aponta que a sociedade esteve envolvida na política pública da abertura da Paulista, \\
desde a mobilização pela ideia, passando pelos debates e enfretamentos dos argumentos contrários, até a \\
acompanhamento de seu funcionamento. \\
\hline $\begin{array}{l}\text { Governança: A regra discerne sobre as práticas de gestão adotadas pela Prefeitura para implementar a } \\
\text { política pública em parceria com a sociedade. }\end{array}$ \\
\hline $\begin{array}{l}\text { Vocação aos Fluxos: Tal regra evidencia que São Paulo é uma metrópole calcada em ideais capitalistas } \\
\text { de competitividade e eficiência e que seus habitantes precisam se manter em movimento para atender } \\
\text { suas necessidades. }\end{array}$ \\
\hline $\begin{array}{l}\text { Má Gestão: A regra denuncia que a Prefeitura foi ineficiente ao gerir as demandas relacionadas à abertura } \\
\text { da Paulista atendendo apenas um dos lados e gerando transtornos ao outro. }\end{array}$
\end{tabular}

Vale lembrar que essas regras seguem quatro critérios: objetos, modalidades, conceitos e estratégias. Sobre os objetos, identificamos o uso do espaço da Avenida Paulista para vivência ou para deslocamento, além da regulação e administração desse espaço. As modalidades presentes foram três: o ativismo, o usuário comum e a gestão da cidade. Os conceitos interpretados foram os de comunitarismo, em oposição ao individualismo; o de democracia e gestão pública; o de progresso; e o de ineficiência do estado, no sentido de denunciar a má-gestão da Prefeitura. Por fim, as estratégias foram a de subversão do espaço, ou seja, novos usos diferentes do previamente planejado; atuação conjunta entre grupos favoráveis e governo; solvência, no sentido de resolução de problemas; e contestação e denúncia de irregularidades. A Figura 3 apresenta como esses critérios se relacionam com as regras. 


\begin{tabular}{|c|c|c|c|c|c|c|c|c|c|c|c|c|c|c|c|c|c|c|}
\hline & \multicolumn{4}{|c|}{ Objeto } & \multicolumn{3}{|c|}{ Modalidade } & \multicolumn{5}{|c|}{ Conceito } & \multicolumn{5}{|c|}{ Estratégia } \\
\hline & & 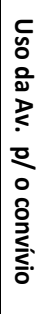 & 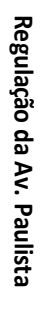 & 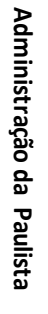 & 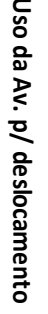 & 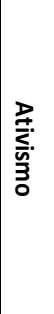 & 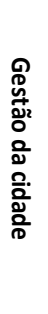 & 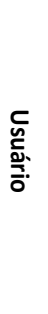 & 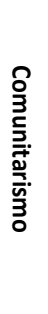 & 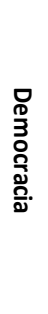 & 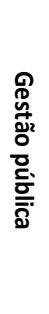 & 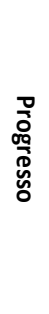 & 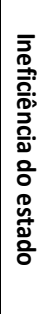 & 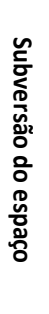 & 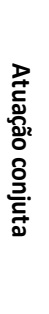 & 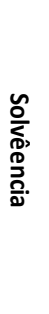 & 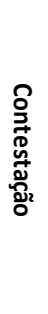 & 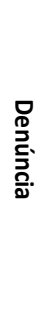 \\
\hline R1 & Nova Cidade & & & & & & & & & & & & & & & & & \\
\hline $\mathrm{R} 2$ & Participação Social & & & & & & & & & & & & & & & & & \\
\hline R3 & Governança & & & & & & & & & & & & & & & & & \\
\hline R4 & Vocação aos Fluxos & & & & & & & & & & & & & & & & & \\
\hline R5 & Má Gestão & & & & & & & & & & & & & & & & & \\
\hline
\end{tabular}

Figura 3 - Relação entre regras e seus critérios.

Apresentadas as regras de formação, passamos para a etapa seguinte, e última, de explanação das formações discursivas.

\subsection{FORMAÇÕES DISCURSIVAS}

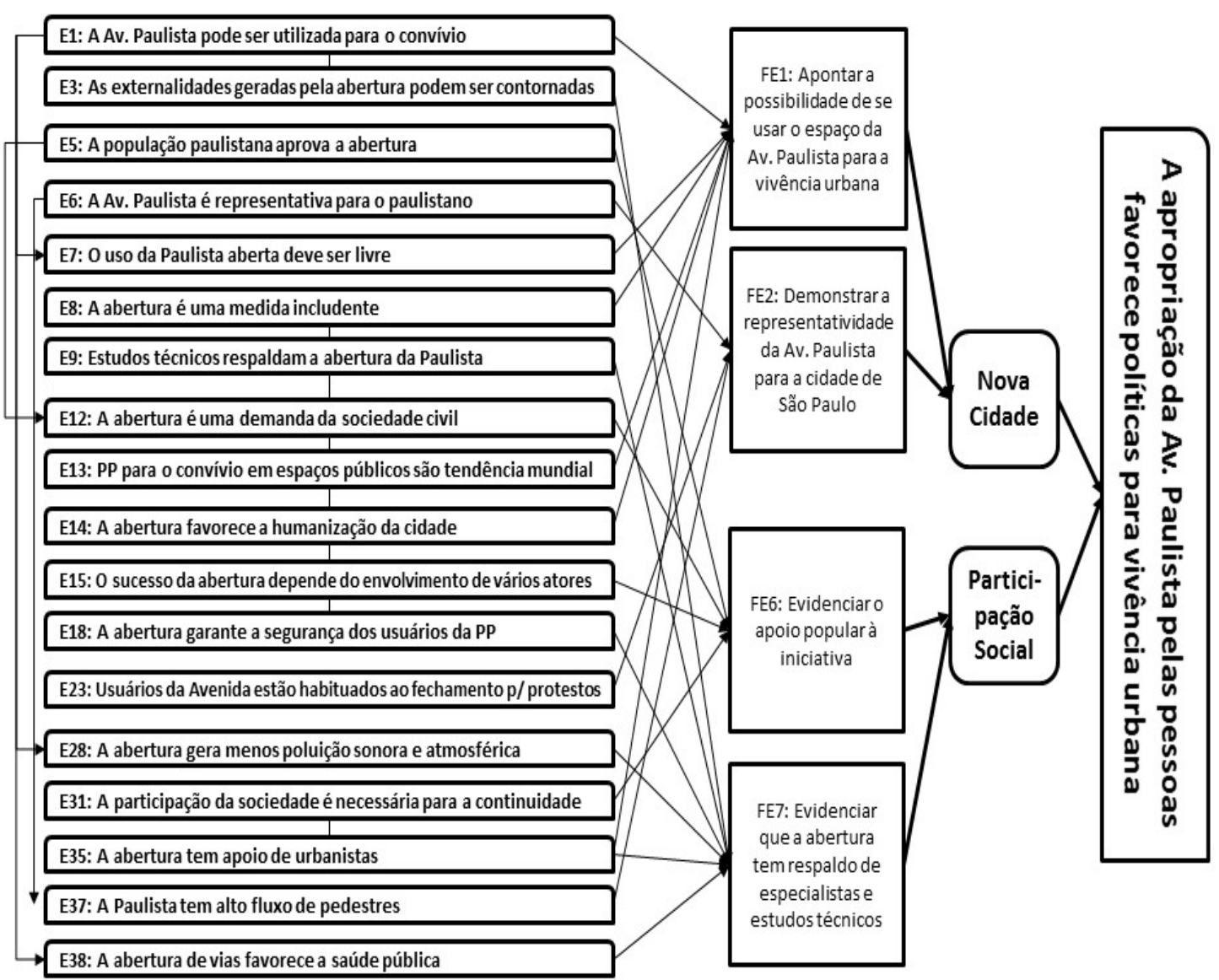

Figura 4 - Formação Discursiva 1. 
A última etapa de nossa ADF foi encontrar as Formações Discursivas presentes no arquivo. Com nossas análises, chegamos a quatro formações. A primeira formação discursiva encontrada foi a seguinte: "A apropriação da Avenida Paulista pelas pessoas favorece políticas para vivência urbana". Tal formação é composta pelas regras "Nova Cidade" e "Participação Social", geradas a partir de quatro funções enunciativas (FE1; FE2; FE6; e FE7). A Figura 4 indica todas as relações, incluindo os enunciados relacionados às funções, que levaram à formação discutida. Apresentamos também, em seguida, alguns exemplos ilustrativos de nossas análises.

O primeiro trecho ilustra os feixes de relações E1-FE1-Nova Cidade e E6-FE2Nova Cidade. O Segundo trecho é referente ao feixe E12-FE6-Participação Social. O Terceiro refere-se ao feixe E35-FE7-Participação Social. Em parênteses, o código do documento de onde o trecho foi retirado.

O projeto Paulista Aberta tem como objetivo oferecer mais espaço de lazer, encontro e atividade física ao cidadão paulistano aos domingos no local mais frequentado e emblemático da cidade - a Avenida Paulista (D04).

Nada disso teria sido possível sem a participação de milhares de pessoas e organizações, que embarcaram em nossa campanha de mobilização pela abertura da Paulista desde 2014, quando a proposta parecia um sonho improvável da SampaPé e a Minha Sampa e uma parcela grande da população ainda repetia os falsos mitos que circulavam sobre a inviabilidade da ideia (D96).

O fechamento de vias como a Paulista para carros aos domingos tem aval de dois em cada três paulistanos (segundo pesquisa Ibope), conta com respaldo majoritário de urbanistas, não enfrentou forte gritaria de hospitais nem de adversários contumazes de Haddad na Câmara (D60).

Essa formação remete a ideias ligadas ao conceito de Cidade para as Pessoas que vimos no início do trabalho e que discutiremos novamente nas conclusões.

A segunda formação discursiva foi: "A participação da sociedade no planejamento de governo foi fundamental para a abertura". A mesma é composta pelas regras "Participação Social" e "Governança", geradas a partir de quatro funções enunciativas (FE3; FE6; FE7; FE9; e FE10), conforme a Figura 5 ilustra. 


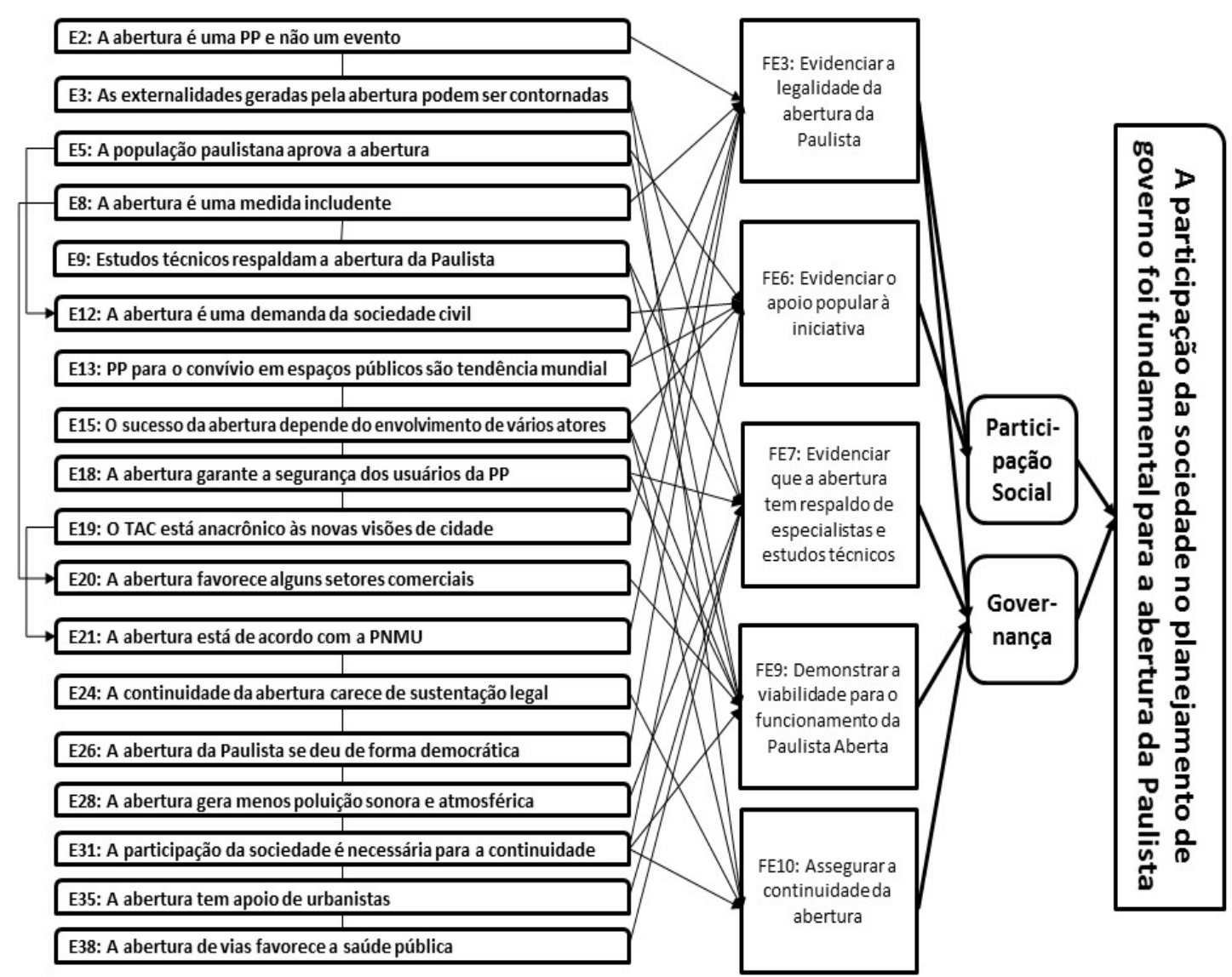

Figura 5 - Formação Discursiva 2.

Exemplificamos nossas análises com os trechos que seguem. O primeiro referente ao feixe E2-FE3-Governança; o segundo ao feixe E26-FE3-Participação Social; o terceiro ao E5-FE6- Participação Social; o quarto ao feixe E18-FE7-Governança; o quinto ao feixe E3-FE9-Governança; e o sexto ao referente ao feixe E31-FE10Governança).

O prefeito já havia afirmado em diferentes oportunidades que o fechamento da Paulista se trata de uma medida de política pública com objetivo de a população se apropriar da cidade e de aumentar os espaços de lazer (D51).

Na reunião, o MPE se posicionou de forma favorável à interdição, que deve ocorrer de forma permanente aos domingos a partir de outubro, mas pediu à Prefeitura que realizasse uma audiência pública para discutir a questão com a população, além de interditar viários também na periferia e reformar clubes municipais (D34).

Pesquisa realizada pelo Ibope revelou que $64 \%$ dos moradores da cidade de São Paulo são favoráveis à utilização exclusiva de ruas e avenidas para lazer e circulação de pedestres e ciclistas aos domingos (D47)

"A decisão é técnica, não pode ser política. Se a CET considera que manter uma faixa aberta vai colocar em risco os pedestres e os ciclistas, essa é uma argumentação técnica, nós levamos ao conhecimento dos 
engenheiros e eles foram unânimes em dizer que uma faixa livre para ônibus e carros vai comprometer a segurança", afirmou. (D61).

A Prefeitura avaliou que, nos dois testes já realizados, não houve impacto significativo para o trânsito (D51).

Para melhorar, mais uma grande novidade. Hoje também foi criado um comitê de avaliação, melhorias e participação do Programa Ruas Abertas que inclui membros da Minha Sampa, SampaPé, Cidade Ativa e Bike Anjo. A proposta principal é incluir você - cidadão e cidadã - em consultas participativas, reuniões e articulações para avaliar e ampliar o programa para as 5 regiões da cidade (D96).

Tal formação discursiva evoca conceitos de democracia e representatividade. Com os atores atuando em parceria para implementar uma política pública para a cidade.

A terceira formação diz: "a abertura da Paulista desafia a vocação da cidade de SP para os fluxos". Esta formação é composta pela regra "Vocação aos Fluxos" que resulta de duas funções enunciativas (FE4; e FE8). A Figura 6 indica todas as suas relações.

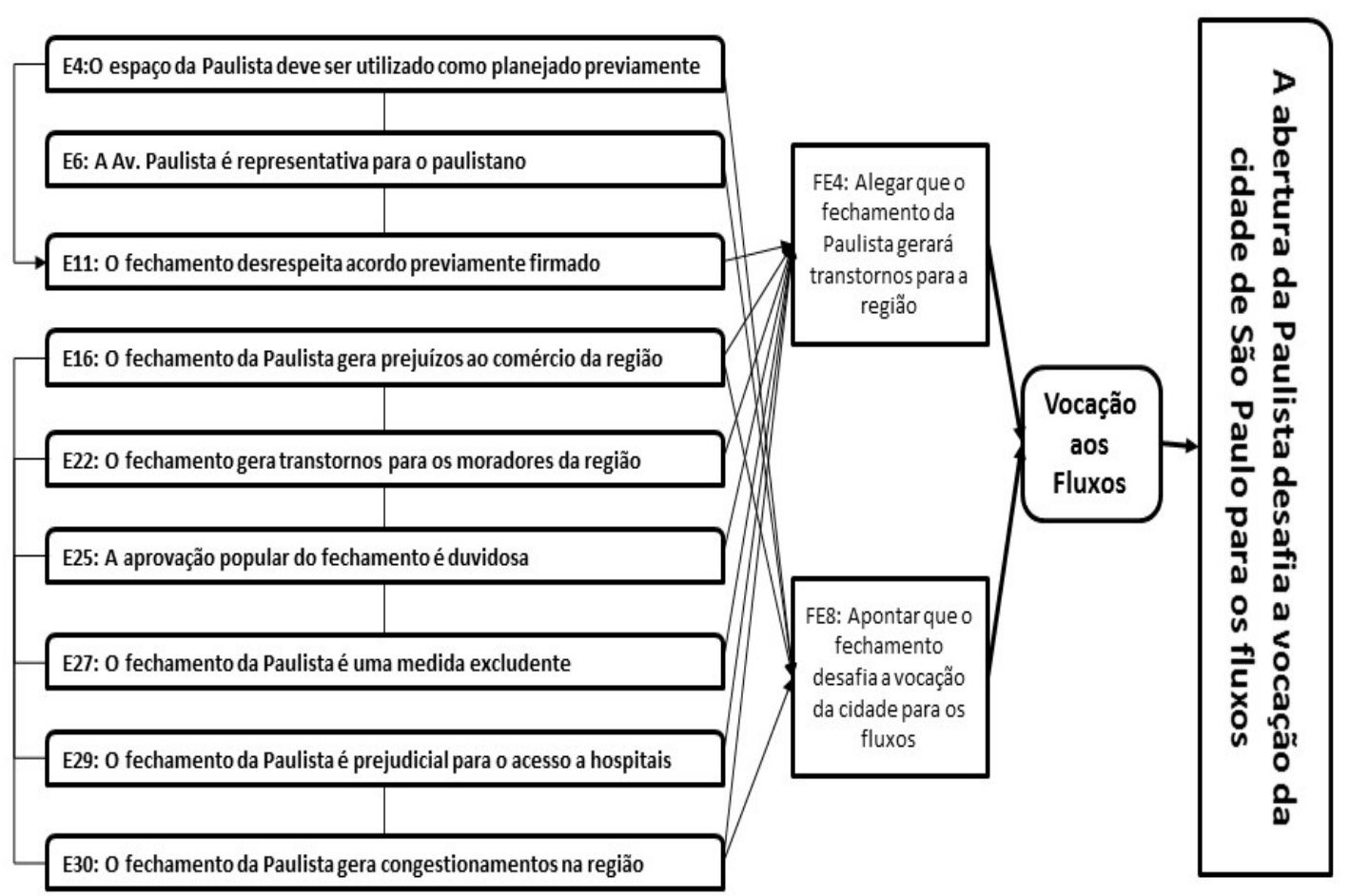

Figura 6 - Formação Discursiva 3.

Escolhemos três trechos que ilustram duas das relações presentes nessa formação. O primeiro pertence ao feixe E4-FE8-Vocação aos Fluxos e dois seguintes ao feixe E22FE8-Vocação aos Fluxos.

Assim, a mais paulista das avenidas jamais se fecha, nunca e a ninguém. É o coração materno e acolhedor da nossa cidade cosmopolita. Foi 
sempre a artéria vital para o pulsar cada vez mais frenético da nossa cidade (D28).

Às $9 \mathrm{~h}$ passa uma sirene avisando que a avenida vai ser fechada. $\mathrm{O}$ mesmo acontece no fim da tarde. Temos dificuldade para entrar nas nossas casas de carro, dificuldade para receber visitas. Você só pode sair a pé ou de bicicleta. (D82).

E parte dos moradores se queixa de barulho, sujeira e reflexos problemáticos no trânsito (D91).

Aqui, o que será discutido nas conclusões relaciona-se à modernidade e os significados que ela carrega e enraíza nas metrópoles ao longo do tempo.

A quarta formação discursiva é "A gestão da cidade é ineficiente em equilibrar diferentes demandas" oriunda da regra "Má Gestão" que é composta por quatro funções enunciativas (FE4; FE5; FE8; e FE11). A Figura 7 ilustra as relações que a criam.

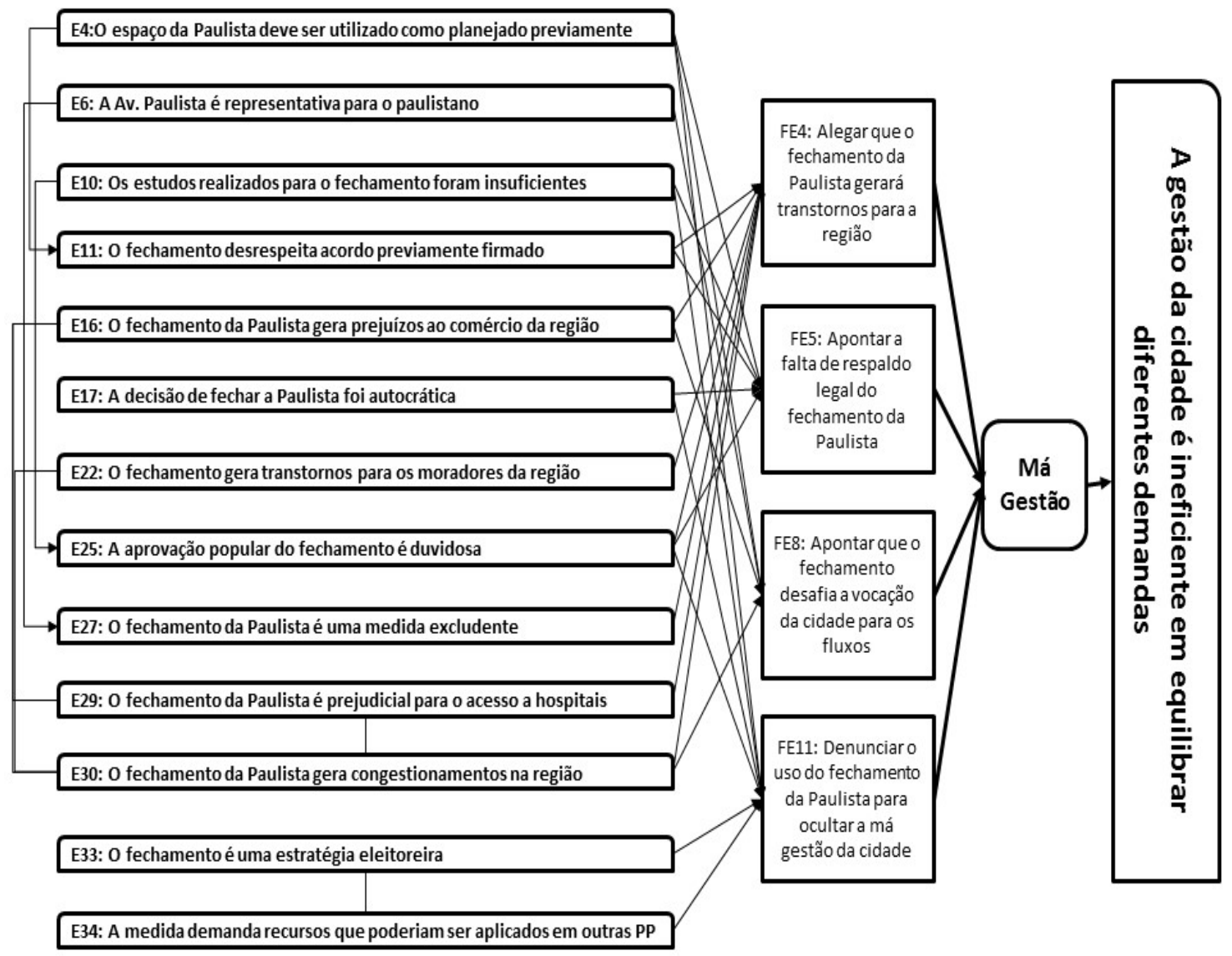

Figura 7 - Formação Discursiva 4.

Para ilustrar as nossas análises a respeito da formação em tela, apontamos trechos referentes aos feixes (E16-FE4-Má Gestão), (E11-FE5-Má Gestão), (E16-FE8-Má Gestão) e (E4-FE11-Má Gestão), respectivamente. 
Uma das principais críticas das associações de moradores da região é que a Prefeitura não avaliou os impactos econômicos que a medida poderá causar aos estabelecimentos (D27).

"Existe um acordo em relação ao fechamento dessa avenida. É uma via que tem muitos hospitais. Sob esse ponto acho complicado negar o acesso. Além disso, há várias áreas de lazer na Paulista, como parques e a própria ciclovia. Acredito que seja suficiente para o lazer. Tecnicamente, sou contrário a esse fechamento", disse (D54).

Diante de tudo isso, a administração municipal se preocupa em fazer alterações drásticas na cidade, com medidas que afetam as atividades econômicas e a vida da população (D21)

Chega a ser devastador: o morador da Paulista observa da janela aquele contingente de policiais que poderiam estar cuidando da segurança da cidade e está deslocado para atender à festinha na porta da casa deles (D94).

Está última formação evidencia os problemas denunciados pelas posições contrárias à abertura da Paulista em relação a atuação da Prefeitura. O que remete a ideia de ineficiência do governo em equilibrar demandas. A Figura 8 resume todas as relações entre funções enunciativas, regras e formações discursivas presentes em nossas análises.

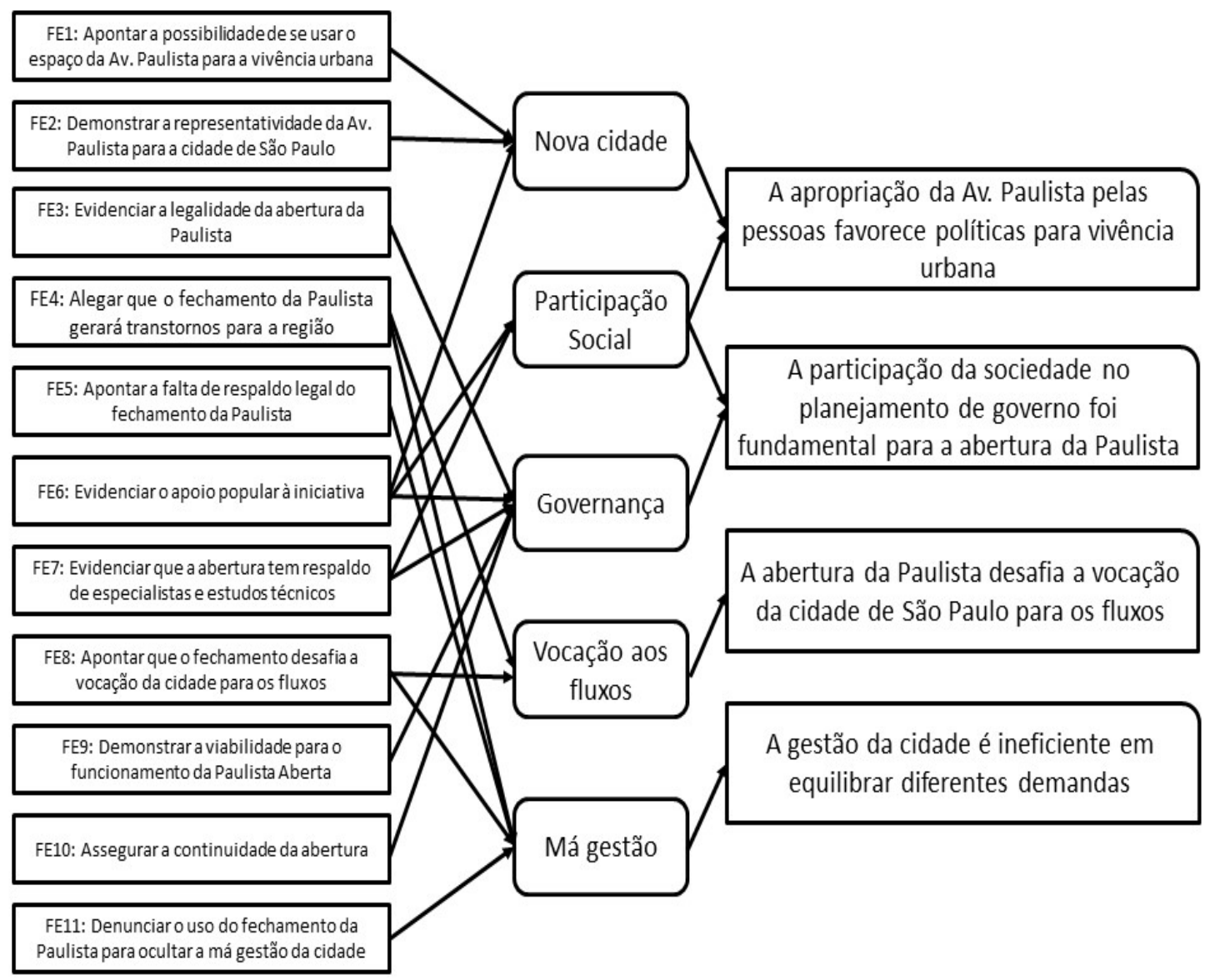

Figura 8 - Resumo de todas as relações entre Funções, Regras e Formações Discursivas. 


\section{ALGUMAS CONSIDERAÇÕES}

Os resultados apresentaram quatro formações discursivas presentes no embate pela abertura da Avenida Paulista. Considerando as articulações que ocorreram entre os domínios estudados, foi possível observar uma visão momentaneamente antagônica entre, de uma lado, Governo e Grupos favoráveis que defendem a ideia, e do outro, Mediador e Grupos contrários, que dela divergem. Relação essa permeada pela Mídia, que tem o objetivo de expor o debate.

Aqueles que defendem a abertura da Avenida Paulista para pessoas propagam discursos que remetem a ideias convivência urbana e participação da sociedade nas decisões públicas, difundidos em duas das formações discursivas observadas. Já os contrários a se fechar a Avenida para os carros pregam o respeito à vocação da metrópole para os negócios, para a circulação de pessoas, bens e mercadorias, e denunciam o não equilíbrio de suas demandas com a de outros grupos envolvidos no embate por parte da Prefeitura, o que aparece nas outras duas formações discursiva encontradas. A oposição deles é visível até mesmo na forma de se expressarem sobre a política pública, com o uso dos termos "abrir" e "fechar" a Avenida Paulista. Para aqueles favoráveis, a política pública está "abrindo" a Paulista para uma série de outras atividades e públicos que não são costumam ter espaço ali. Para os contrários, a política pública está "fechando" uma Avenida de grande interesse para a circulação e deslocamento na cidade.

Considerando que as cidades assumiram definitivamente centralidade na criação e dinamização de bens simbólicos e no bem-estar de sua população (CASTELLS; BORJA, 1996). Os discursos presentes parecem disputar o modelo de cidade "ideal" que São Paulo deveria se tornar. De um lado, provisoriamente, estão os que anseiam por tornar a metrópole paulistana mais humana, com seus espaços públicos resgatando a função social de lugar de encontro e que possam ser democraticamente geridos por toda a população. O que coaduna com o conceito de Cidade para Pessoas. Segundo Gehl (2013), o espaço público da cidade democraticamente gerido garante acesso e oportunidades de expressão de todos os grupos da sociedade e liberdade para atividades alternativas, demonstrando as oportunidades do espaço público de reforçar a sustentabilidade social, o que é uma dimensão muito maior do que ver o espaço da cidade apenas como arena comercial particular.

Do outro lado, no entanto, estão os defensores da hegemonia urbana paulistana. Hegemonia no sentido, dado por Laclau e Mouffe (2015), de prática que representa a articulação de diferentes identidades e subjetividades por meio de atividades políticas para constituírem e disseminarem determinada ordem social, que no caso da cidade de São Paulo é a de espaço para os fluxos, para o movimento de mercadorias e pessoas. Tal metrópole se desenvolveu sob uma lógica de automobilidade e pautada por valores neoliberais de liberdade econômica e do indivíduo, fazendo sua população a ela se adaptar. Um tipo de racionalidade que ao ser desafiada por uma nova forma de ver o urbano, faz sua população adaptada sentir-se prejudicada e criticar a mudança.

Assim, tal embate parece ressaltar aquilo que Castells (2004) afirmara sobre a estruturação das cidades se dar por lógicas concorrentes e simultâneas de espaços de fluxos e espaços de lugar. Como uma hegemonia depende da articulação dos sujeitos políticos e que esses mesmos sujeitos têm posições provisórias e contingentes sobre o tema. Como, por exemplo, o fato de a Prefeitura ser hoje representada por espectro 
político oposto ao anterior. Assim, a disputa pelo uso do espaço na Paulista tende a ser um conflito permanente.

\section{REFERÊNCIAS}

BRAY, Paul. The New Urbanism: celebrating the city. Places, v. 8, n. 4, 1993.

CASTELLS, Manuel. Space of flows, space od places: materials for a theory of urbanism in the information age. In: GRAHAM (ed.). The cyber cities reader. New York: Routledge, 2004.

; BORJA, J. As Cidades como atores Políticos. Novos Estudos CEBRAP, n. 45, julho, p. 152-166, 1996.

CORREIA, Telma de Barros. Espaço, tempo e cidade: as tecnologias da velocidade e o ambiente urbano. Em: XX Encontro Nacional da ANPOCS, Anais eletrônicos..., Caxambú, ANPOCS, 1996.

ELLIS, Cliff. The New Urbanism: critiques and rebuttals. Journal of Urban Design, v. 7, n. 3, p. 261-291, 2002.

FISCHER, Rosa Maria Bueno. Foucault e a análise do discurso em educação. Cadernos de Pesquisa, Rio de Janeiro, n. 114, 197-223, 2001.

FOLHA. Atropelos para fechar paulista ofuscam ação respaldada por urbanistas. Folha de São Paulo. 16 out. 2015. Disponível em: http://www1.folha.uol.com.br/cotidiano/2015/10/1694622-atropelos-para-fecharpaulista-ofuscam-acao-respaldada-por-urbanistas.shtml. Acesso em 22 nov. 2015.

FOUCAULT, M.. A arqueologia do saber. $7^{\mathrm{a}}$. ed. Rio de Janeiro: Forense, 2008.

GEHL, Jan. Cidade para Pessoas. $2^{\text {a }}$. ed. São Paulo: Perspectiva, 2013.

GONÇALVES, S.C. O método arqueológico de análise discursiva: o percurso metodológico de Michel Foulcault. História e-História, v.1, 1-21, 2009.

HARVEY, David. Neoliberalismo como destruição criativa. Interfacehs - Revista de Gestão Integrada em Saúde do Trabalho e Meio Ambiente, v. 2, n. 4, ago 2007.

JACOBS, J. Morte e vida de grandes cidades. 3ª ed. São Paulo: Martins Fontes, 2011.

KELBAUGH, Douglas. Three paradigms: new urbanism, everyday urbanism, posturbanism. Bulletin of Science, Technology \& Society, v. 20, n. 4, 285-289, 2000.

LACLAU, Ernesto; MOUFFE, Chantal. Hegemonia e estratégia socialista: Por uma política democrática radical. São Paulo: Intermeios, 2015.

LEÃO, André Luiz Maranhão de Souza; FERREIRA, Bruno Rafael Torres; GOMES, Victor Pessoa de Melo. Um "elefante branco" nas dunas de Natal? Uma análise pós- 
desenvolvimentista dos discursos acerca da construção da Arena das Dunas. Rev. Adm. Pública, v. 50, n. 4, 659-687, jul./ago. 2016.

LEFEBVRE, Henri. O direito à cidade. São Paulo: Centauro, 2001.

MINHASAMPA. Por uma São Paulo mais humana. Paulista Aberta. 2016. Disponível em: http://www.paulistaaberta.minhasampa.org.br/. Acesso em 10 fev. 2016.

PAIVA JUNIOR, Fernando Gomes de; LEÃO, André Luiz Maranhão de Souza; MELLO, Sérgio Carvalho Benício de. Validade e Confiabilidade na Pesquisa Qualitativa em Administração. Revista de ciências da administração, v, 13, n. 31, 170-209, set./dez. 2011.

PEREIRA, Ingridd Michelle Lopes; CHAGAS, Pedro Dolabela. Arquivo e Memória: uma análise dos conceitos de arquivo segundo Michel Foucault e Roberto Gonzalez Echevarría. Fólio [Ver. de Letras Vitória da Conquista], v. 3, n. 2, 319-331, jul./dez. 2011.

PFEIFFER, Claudia Castellanos. Sentidos na cidade: clichê e sujeito urbano. RUA, Campinas, SP, v. 3, n. 1, 37-58, out. 2015.

PMSP. Moradores decidem quais ruas poderão ser abertas para ciclistas e pedestres em seus bairros. Prefeitura de São Paulo. 29 set. 2015. Disponível em: http://capital.sp.gov.br/portal/noticia/6039. Acesso em 18 out. 2015.

PMSP. Prefeitura institui oficialmente programa ruas abertas. Prefeitura de São Paulo. 29 dez. 2016. Disponível em: http://capital.sp.gov.br/noticia/prefeitura-institui-oficialmenteprograma-ruas-abertas. Acesso em 11 jan. 2017.

PROJECT FOR PUBLIC SPACES. Streets as Place: Using Streets to Rebuild Communities. Nova Iorque: PPS, 2008.

ROLNIK, Raquel; KLINTOWITZ, Danielle. (I)Mobilidade na cidade de São Paulo. Estudos avançados, v. 25, n. 71, 2011.

SIMMEL, G. As grandes cidades e a vida do espírito. Mana, v. 11, n. 2, 577-591, 2005.

TOURAINE, Alain. Crítica da modernidade. Petrópolis: Vozes, 1994.

URRY, John. Governance, flows, and the end of the car system? Global Environmental Change, v. 18, 343-349, 2008.

Artigo recebido em: novembro de 2017.

Aprovado e revisado em: fevereiro de 2018.

Publicado em: maio de 2018. 


\section{Para citar este texto:}

BASTOS, Antonio Fagner da Silva; MELLO, Sérgio Carvalho Benício de. Desafiando a vocação da metrópole: uma análise dos discursos presentes nas disputas pelo uso da Avenida Paulista na cidade de São Paulo. Entremeios [Revista de Estudos do Discurso, ISSN 2179-3514, on-line, www.entremeios.inf.br], Seção Estudos, Programa de PósGraduação em Ciências da Linguagem (PPGCL), Universidade do Vale do Sapucaí (UNIVÁS), Pouso Alegre (MG), vol. 16, p. 171-192, jan. - jun. 2018.

DOI: http://dx.doi.org/10.20337/ISSN2179-3514revistaENTREMEIOSvol16pagina171a192 